\title{
Vergelyking van die parasietgemeenskapsamestelling van Xenopus laevis (Anura: Pipidae) tussen gasheerbevolkings regoor die wêreld
}

\begin{abstract}
Outeurs:
Anneke L Schoeman, ${ }^{a, b}$

LH du Preez

Affiliasies:

${ }^{a}$ Eenheid vir Omgewings-

wetenskappe en -bestuur,

Noordwes-Universiteit

Privaatsak X6001,

Potchefstroom, 2520

bentrum vir Indringer-

biologie, Departement

Plant- en Dierkunde,

Stellenbosch Universiteit

'Suid-Afrikaanse Instituut

vir Akwatiese Biodiversiteit,

Grahamstad
\end{abstract}

Korresponderende outeur:

AL Schoeman

E-pos:

anneke.lincoln@gmail.com

Hoe om hierdie artikel aan te haal:

Anneke L Schoeman,

LH du Preez, Vergelyking van

die parasietgemeenskap-

samestelling van Xenopus

laevis (Anura: Pipidae)

tussen gasheerbevolkings

regoor die wêreld, Suid-

Afrikaanse Tydskrif vir

Natuurwetenskap en

Tegnologie 38(1) (2019).

https://doi.org/10.36303/

SATNT.2019.38.1.775

Kopiereg:

C 2019. Authors

Licensee: Die Suid-

Afrikaanse Akademie vir

Wetenskap en Kuns.

Hierdie werk is onder

die Creative Commons

Attribution License

gelisensieer.
Comparison of the parasite communities of Xenopus laevis (Anura: Pipidae) across its global distribution: Xenopus laevis is a global invader with many parasites - thus an ideal model to test hypotheses in invasion biology. This study shows that invasive $X$ laevis populations harbour less parasites than their native counterparts and that certain parasites co-diverge with their host, acting as biological markers to track host dispersal.

Tydens die Antroposeen neem party spesies se bevolkingsgetalle dramaties af, terwyl ander spesies ongekende uitbreiding beleef. Die gewone platanna, Xenopus laevis (Anura: Pipidae), en sy parasiete bied ' $n$ ideale model om die lot van suksesvolle indringerspesies te bestudeer. Die toename van die platanna het in die 1930's begin toe dit aanvanklik as biologiese swangerskaptoets en later as modellaboratoriumorganisme vanuit Suid-Afrika uitgevoer is. Vanweë die invloed van veranderende klimaatsomstandighede is $X$. laevis se voortgesette gebiedsuitbreiding onstuitbaar en word indringerbevolkings tans op vier kontinente aangetref. Verder word X. laevis ook gekenmerk deur 'n unieke en spesieryke parasietfauna. Meer as 25 parasitiese invertebraatgenera word met die platanna in sy inheemse verspreidingsgebied geassosieer. Boonop vergesel van hierdie parasiete hulle gasheer en tree as mede-indringers op. Om die bestaande bestuurspraktyke van hierdie indringer toe te lig, is dit onontbeerlik dat die verspreidingspatrone en taksonomie van sy parasiete opnuut aandag kry.

Tydens hierdie studie is 187 volwasse X. laevis vanaf 28 lokaliteite in suidelike Afrika en 'n bykomende 43 van ses lokaliteite in westelike Frankryk ingesamel. Alle eksterne en interne invertebraatparasietspesies is verwyder ná eties aanvaarbare eutanasie. Hierdie data is verder geanaliseer, tesame met reeds gepubliseerde data van die parasietgemeenskappe van 489 platannas vanuit die uitheemse gebiede van Kalifornië, Chili en Portugal.

Die parasietopname in suidelike Afrika het 21 spesies opgelewer, waarvan 13 reeds aan die wetenskap bekend is. Omdat selfs die reeds beskrewe parasietspesies se taksonomiese inligting maar skraps is, is die spesiebeskrywings van drie nematode van die spysverteringskanaal opgedateer met nuwe verspreidings-, molekulêre en morfologiese data. Verder is die genetiese en morfologiese diversiteit van die polistoom $P$. xenopodis, een van die platanna se mees algemene mede-indringers, oor sy totale verspreidingsgebied ondersoek. Daar is bevind dat die polistome vanaf die noordelike gedeeltes van suidelike Afrika beduidend verskil van hulle naamgenote in die suidwestelike gebiede. Op grond van hierdie variasie is hulle besonder geskik as biologiese merkers om die beweging van hulle gasheer oor die gebied te volg. Die intieme verhouding tussen hierdie gasheer-spesifieke parasiet en $X$. laevis is verder bevestig deur ko-filogenetiese ondersoeke wat getoon het hoe divergerende populasies binne parasietspesies met hulle gasheer se filogeografie ooreenstem. In teenstelling met die inheemse gebied se spesierykheid is die parasietgemeenskappe van die indringerplatannas beduidend verarm. 'n Merkbare patroon van parasietverlies is ook in die inheemse populasies van die platannas aangeteken wat deel van pioniergemeenskappe of versteurde habitatte gevorm het. Die verlies aan natuurlike vyande kan gesien word as een van die redes waarom $X$. laevis so suksesvol is, nie net as indringer in die buiteland nie, maar ook in sy natuurlike gebied, waar dit 'n welbekende pionierspesie met 'n hoë verspreidingsvermoë is.

Ons resultate bevestig die waarskuwings van verskeie ander wetenskaplikes, naamlik dat parasiete indringers in eie reg is en dat hulle invloed op hul indringergashere en nuwe omgewings nie onderskat moet word nie. Verder tree X. laevis as 'n indringer met'n wêreldwye verspreiding en verskeie ko-evolueerde parasiete as ' $n$ ideale model na vore wat as 'n globale eksperiment kan dien om die faktore wat bydra tot gebiedsuitbreiding te identifiseer.

Nota: 'n Seleksie van referaatopsommings: Studentesimposium in die Natuurwetenskappe, 25-26 Oktober 2018, SA Akademiegebou, Pretoria, Suid-Afrika. Gasredakteurs: Prof Rudi Pretorius (Departement Geografie, Universiteit van Suid-Afrika); Prof Chris Swanepoel (Departement Besluitkunde, Universiteit van Suid-Afrika); Me Andrea Lombard (Departement Geografie, Universiteit van Suid-Afrika) 